\title{
WATER RETENTION MEASURES - CASE STUDY FROM SLOVAKIA
}

\author{
MARTINA ZELEŇÁKOVÁ ${ }^{1}$, MARIA MANUELA PORTELA ${ }^{2}$ \& PETR HLUŠTÍK ${ }^{3}$ \\ ${ }^{1}$ Institute of Environmental Engineering, Faculty of Civil Engineering, Technical University of Košice, \\ Košice, Slovakia \\ ${ }^{2}$ Department of Civil Engineering, National Technical University of Lisbon, Lisbon, Portugal \\ ${ }^{3}$ Institute of Municipal Water Management, Faculty of Civil Engineering, Brno University of Technology, \\ AdMaS centre, Brno, Czech Republic
}

\begin{abstract}
Water retention measures are multi-functional measures that aim to protect water resources using natural means and processes. These measures can contribute to reducing the risk of floods and water scarcity and drought while also improving the status of surface and ground water bodies. Water retention measures can support the achievement of the goals of a range of EU policies, including those for surface water, groundwater and coastal management, nature conservation, agriculture, forestry, urban water management, disaster risk management, green growth and climate change mitigation and adaptation. This article presents water retention measures suitable for application in urban areas. Infiltration of rainwater, taking into account the suitability of local conditions, appears to be the most environmentally suitable solution of rainwater drainage. The connection of conventional method of draining rainwater through sewer systems and infiltration of rainwater appears to be the most suitable drainage concept for sustainable cities. Keywords: infiltration, rainwater management, urban areas
\end{abstract}

\section{INTRODUCTION}

Water retention measures are multi-functional measures that aim to protect and manage water resources using natural means and processes, thereby building up Green Infrastructure, for example, by restoring ecosystems and changing land use (European Union, NWRM project $[1,2])$. These measures have the potential to provide multiple benefits, including flood risk reduction, water quality improvement, groundwater recharge and habitat improvement. As such, they can help achieve the goals of key EU policies such as the Water Framework Directive 2000/60/EC [3] and the Floods Directive 2000/60/EC [4]. Figure 1 illustrates selected EU policy initiatives recognized in the potential role of water retention measures in contributing to the achievement of their objectives.

Water retention measures can contribute to both Water Framework and Flood Directive goals and can enhance synergies between the implementation of both directives and support the coordination between the River Basin Management Plans and Flood Risk Management Plans. The uptake of these measures in management plans is triggered through the potential to improve or preserve hydro-morphological conditions, as well as the water quantity and quality.

New approach towards urban water management includes a number of tools which enable to reduce environmental effects of urbanization and maintain purpose of the area. In recent years, the implementation of several different types of object infiltration in Europe and overseas has led to errors in their planning and operation caused by neglected scientific claims. However, in an area where poorly permeable rocks appear, subsurface water infiltration must be carried out very cautiously. Meeting the requirements for collecting rain water for the land property must proceed with the professional care so that it does not damage the objects (European Union, NWRM project $[1,2])$. Nowadays, runoff process and rainwater management 


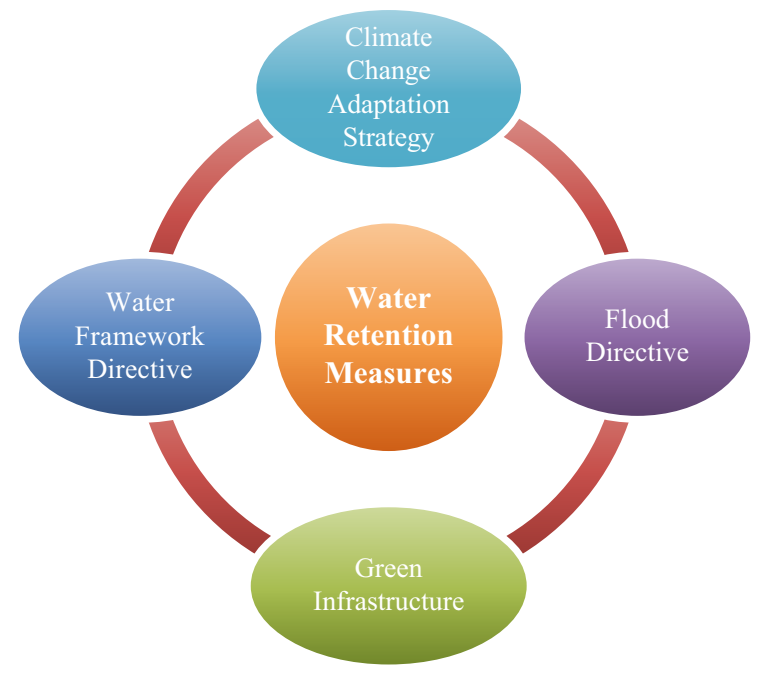

Figure 1: Water retention measures and selected EU policy initiatives.

are inevitable topics of research in the time of climatic variability. Rainwater management should be considered as a sustainable strategy for reconstruction of rural and urban settlements from the aspects of environmental management and social criteria (Markovič et al. [5]). There are many possibilities which can reduce the risk of flooding and regulate the quantity and quality of groundwater. Most of these possibilities are proposed only by theoretical calculation based on standards (Standard DWA-A 138E [6]). Best management practices reflect the natural process of rainwater management that can be found in non-urban basins and their transformation to urban areas.

The following sections present selected water retention measures applicable in urban areas - a case study from Košice City in Slovakia.

\section{STUDY AREA}

Košice is the second largest city in the Slovak Republic. It consists of 22 city boroughs, among which is the new project Nová Terasa located on the border of the city borough Staré Mesto in the near vicinity of Košice's historical centre. The project brings modern architecture, a characteristic feature of which is the exclusiveness of mutually linked buildings, which together form an enclosed interior courtyard. The Nová Terasa project (Fig. 2) offers a wide selection of different types of flats. In the first phase a total of 199 one- to four-room flats were built with floor space from 31 to $110 \mathrm{~m}^{2}$. The flats are orientated directly on the centre of Košice, in close vicinity of the hospital, or on the slope of the hills.

A system for drawing away rainwater from the roofs, car parks and local paths and roads has been designed for the site. Rainwater from roads and car parks from all stages will be harvested using rainwater traps. The water, including rainwater from roofs, will subsequently be carried into a retention tank with throttled discharge using a whirling flow regulator at $25 \mathrm{~L} / \mathrm{s}$ per one stage. From this it follows that from all four stages the permitted amount of rainwater $(100 \mathrm{l} / \mathrm{s})$ will be released into the sewerage system. Rainwater will be taken from the retention tank to an oil-water separator with a guaranteed discharge up to $1.0 \mathrm{mg} \mathrm{NEL/1}$ Macurová [7]. 


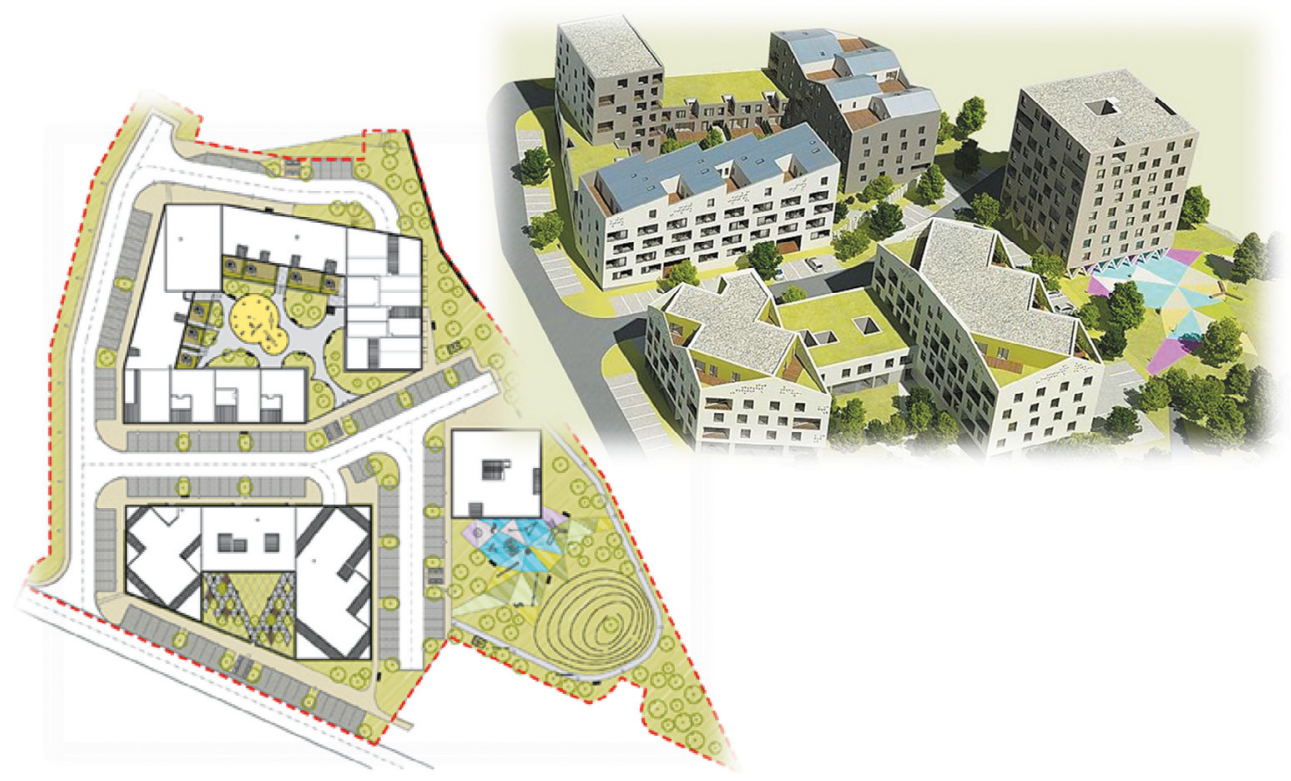

Figure 2: Nová Terasa project.

The original design resolves the possibility of taking rainwater away from the residential area and into the public sewerage system. The pipes will be connected to the existing sewerage network, terminated by a sewerage shaft in the pavement. The route will consist of ribbed sewerage pipes and sewerage shafts of $\varnothing 1.0 \mathrm{~m}$ will be placed along it. On the request of Eastern Slovakia Water Supply Company, to limit the discharge of rainwater to $100 \mathrm{l} / \mathrm{s}$, a throttling section with a $0.6 \%$ gradient will be established on the main path, to which a pipe connected to the existing sewerage system will be led. Slowing the discharge of rainwater will be resolved in the scope of drainage of roads and paved surfaces by establishing a retention tank with a throttled discharge to $25 \mathrm{l} / \mathrm{s}$.

\section{RESULTS}

Alternative option for rainwater management, which is proposed for this new urban settlement, is presented in the following.

From a geological survey of the site where construction of the first stage of the project is currently taking place, it follows that the territory is not suitable for absorption facilities (Zelenakova and Hudakova [8]). Therefore, a retention tank was considered in the original proposal. In the subsequent proposal, alternative facilities are proposed for the trapping and accumulating of rainwater, namely

- Absorption blocks

- Absorption wells

- Infiltration pond

These alternative possibilities for trapping rainwater are proposed for the nearby street, to where the rainwater would be taken. Based on the geological survey performed, conditions on nearby street are evidently suitable for absorption. 


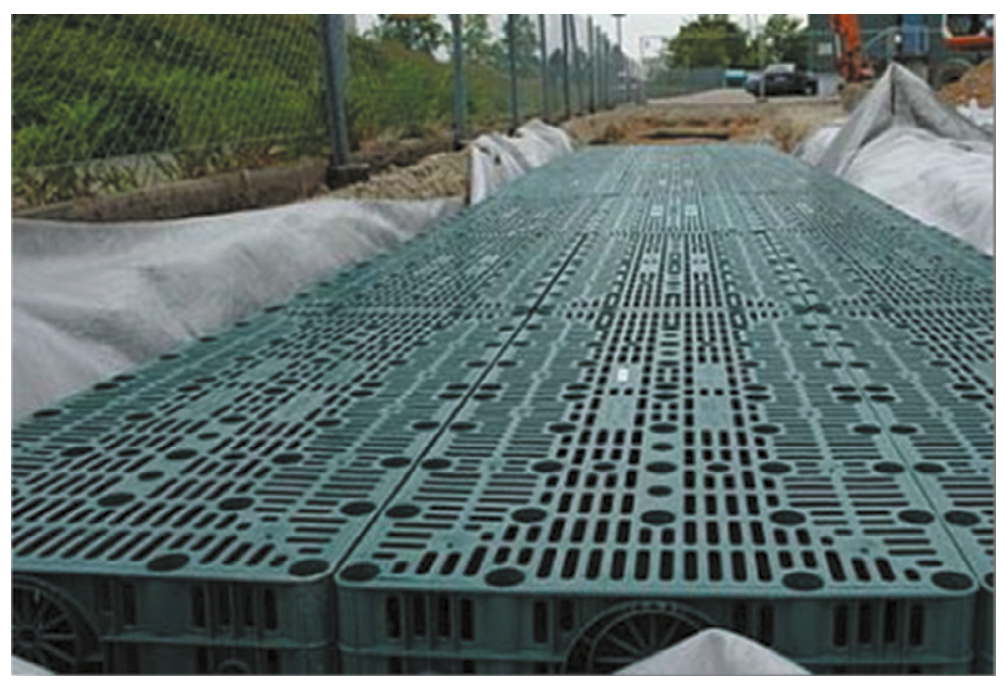

Figure 3: Absorption blocks.

\subsection{Absorption blocks}

Rainwater is led underground into hollow absorption boxes (Fig. 3), where it is temporarily accumulated, and based on the permeability of the soil, infiltrates little by little into the ground. The blocks are also suitable where there is a smaller amount of space for absorption. They are expanded to all sides and combined into optionally large facilities. They also contain a transverse inspection tunnel, which enables inspection by camera or the flushing of the entire system.

Rainwater from car parks will be taken to an oil-water separator, from which, after removal of hazardous substances, it will be fed together with rainwater from the roof into the underground absorption space located near the Elementary School on a street in the vicinity of Kuzmány Street in Košice. The amount of water $q$ which is absorbed, with a value of $0.78 \mathrm{l} / \mathrm{s} / \mathrm{m}^{-2}$, is calculated on the basis of the coefficient of filtration known from a hydrogeological survey in the given area. This means that for every $1 \mathrm{~m}^{2}$ of surface, 0.781 of rainwater is absorbed into the subsoil. The total amount of rainwater carried for absorption from all stages is known: $695.5 \mathrm{l} / \mathrm{s}$. The absorption area is the area which is formed for the most part by the base on which the absorption blocks are placed of $480 \mathrm{~m}^{2}$ - area available for placement of absorption blocks.

\subsection{Absorption wells}

Absorption wells (Fig. 4) collect rainwater from the roofs of houses, car parks, surfaces, etc. and return it to the groundwater. They have a large spatial volume, i.e. such that each well may absorb a great amount of water. They are usually made from perforated pipes through which rainwater is absorbed into the subsoil. Drilled wells compared with a dug well absorb deeper groundwater, which is not directly dependent on precipitation and its amount remains more consistent over the course of the whole year. The drawn water also wields better quality. In the second alternative solution for trapping rainwater, water from roofs and car parks is taken to a retention container with a throttled discharge. From there it passes through an 


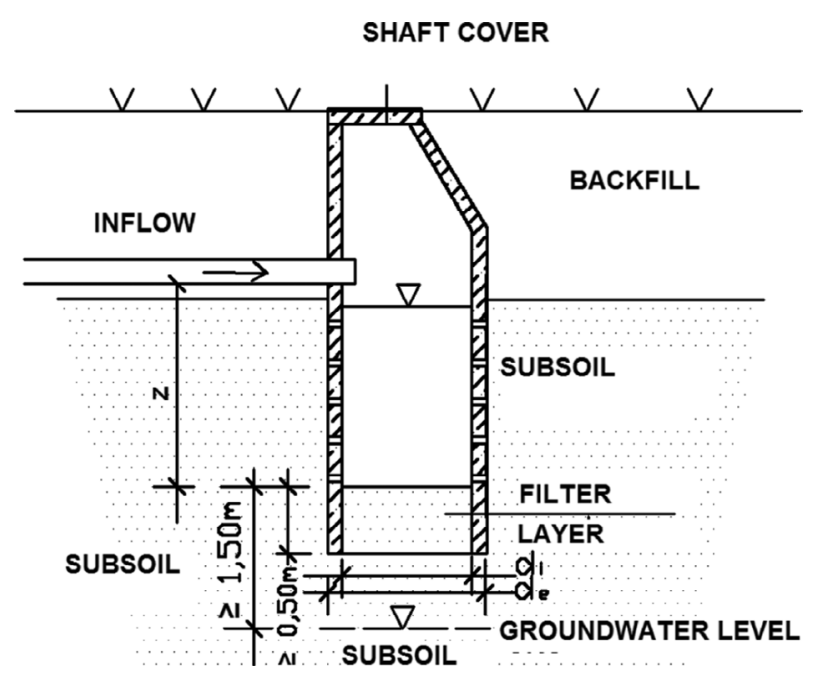

Figure 4: Absorption wells.

oil-water separator and is then taken to drilled absorption wells. Only sinkwater is released into the sewerage system.

In the scope of the second alternative solution for trapping rainwater, 10 absorption wells with a separation of $2 \mathrm{~m}$ will be proposed for the selected site. The wells will be mutually interconnected by pipes of diameter DN 150 . The dimensions of absorption wells will be as follows: the depth is $15 \mathrm{~m}$, diameter $0.35 \mathrm{~m}$.

\subsection{Infiltration pond}

The already created shallow depression in the lawn enables the larger part of the water to remain on the site. If this depression is put in a place with permeable soil, it can serve for infiltration (Fig. 5).

Large buildings (like the newly designed Nová Terasa site) ensure a sufficient amount of water for establishing a closed infiltration pond, which enables the permanent planting of banks with wetland vegetation. An accumulation space for the trapping of rainwater is created over the permanent level of the water. The banks above the plain of the permanent level are made from permeable rock, and the held water gradually soaks into the surrounding soil. The third alternative solution is designed using an infiltration pond. The water from roofs

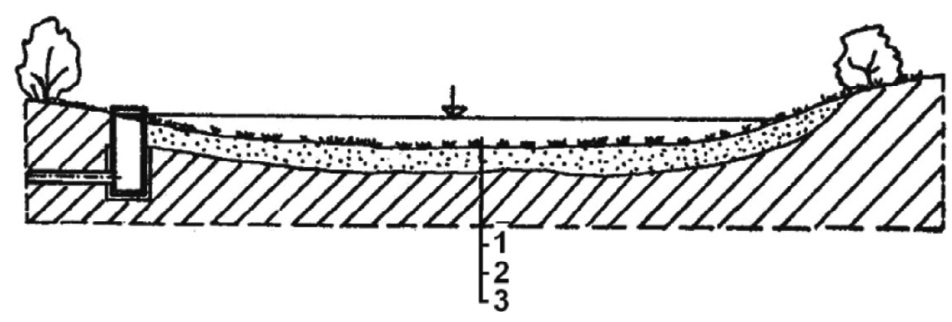

Figure 5: Infiltration ponds, 1-infiltration basin, 2-permeable ground, 3-sand. 
together with water from car parks flows into a retention tank with a throttled discharge, from where it is taken for absorption to the infiltration pond. Sinkwater is taken independently to the public sewerage system. The proposed pond absorbs rainwater from all constructions. It has the shape of a basin, i.e. it has the greatest depth in the centre and towards the edges its depth declines. Area of infiltration pond will be $18 \times 25 \mathrm{~m}$. Average depth of the pond will be $1.5 \mathrm{~m}$. Finally the total volume of the pond will be $675 \mathrm{~m}^{3}$.

\subsection{Evaluation of the alternative proposals}

This work presents a proposal of alternative possibilities for the trapping of rainwater for the newly built project Nová Terasa on Ondavská Street in Košice. This proposal consists in the selection of the most suitable solution from among absorption blocks, absorption (drilled) wells and an infiltration pond. The proposal of absorption blocks is considered as the most suitable alternative solution for rainwater management, because though they are more expensive than an infiltration pond, they do not represent a danger to the children living in the vicinity, and an additional playground can be built over them. All alternative methods of trapping rainwater ensure an easing on the public sewerage system, which was also an aim of this work.

Effective devices in urban areas designed for fluent infiltration of rainwater from the roofs of buildings and paved surfaces are infiltration facilities (Slys [9]). The basic principle and function of all types of infiltration facilities is to divert rainwater as quickly as possible to infiltration zone, and there it infiltrates into the surrounding soil (Markovič et al. [3]). Design and use of infiltration facilities as a sustainable method of rainwater runoff disposal become an integral part of the drainage management and projects of sewerage system of buildings or other paved surfaces. Disposal, especially safe drainage of rainwater, is a problem of almost every new building in an urban area and in area with undersized sewage systems.

Wastewater disposal systems, sewage treatment plants and recipients of water flows are overloaded and the risk of floods grows. This represents another reason for waterworks companies to have the possibility of forbidding the disposal of rainfall water from surface detention into the wastewater disposal system already present during the creation and fulfillment of the development plan. This leads to the necessity of using rainwater infiltration systems or capturing rainwater for further reuse. Infiltration systems not only solve a technical problem that partially relieve a sewer network but also contribute to the ecological stability of ecosystems; in addition, they reduce the expense for disposal of rainwater. Although infiltration systems are not new in urban drainage, they were seldom used in the past. Nowadays its utilization is increasing, which presents the novelty of urban drainage solution. These systems contribute to refurbishing the aquifer and river basins generally.

\section{CONCLUSION}

Many cities and urban areas are located in flood plains because the land is fertile and flat which is suitable for agriculture and urban development. Rivers provide water supply for domestic, industrial and irrigation uses; they also provide convenient means for navigation, transportation and communication. Cities have large percentage of impervious areas that prevent effective infiltration of rainfall into soil. To have successful flood control and flood risk management, we should consider not only hydraulic and engineering aspects but also socioeconomic and environment aspects (Slys [9]). Flood management should have involvement of various stakeholders, including concerned authorities such as urban planners, civil and 
water resources engineers, civil disaster defense authorities and health and social services. The best flood mitigation measures from all main points of view - social, economic and environmental - are natural water retention measures.

Water retention measures cover a diversity of measures that are implemented by different sectors or considered in different planning processes dealing with water, food risk management, biodiversity protection, climate change adaptation or urban planning. Some of these measures aim to directly modify the ecosystem, while others focus on changes of practice of economic operators.

The concept of drainage in cities, which aims to mitigate the impact of urbanization on the hydrological regime of the country and on aquatic ecosystems, come from our experiences and knowledge of current method of sewerage. New concept of capture and use water from surface run-off provides a platform for a new technical and non-technical measures, both that is drained on each property and in the public part of urban drainage area.

Suitability of choice of type of infiltration facility is dependent on local conditions. In each case, it is to be considered carefully, which drainage concept in combination with the percolation of precipitation is ecologically sensible, technically possible and economically justifiable (Slys et al. [10]).

This work deals with the issue of rainwater management. This article presents water retention measures suitable for application in urban areas. The practical part presents a proposal for trapping rainwater on the selected territory of the newly designed project Nová Terasa in Košice.

This proposal resolves alternative possibilities for taking away rainwater rather than sending it to the public sewerage system. In the original design, rainwater is taken for accumulation into a retention tank with a safety overflow and throttled discharge. After passing through an oil-water separator, it is taken along with sinkwater into the public sewerage system. For alleviating the sewerage network, a system for taking off rainwater for absorption was proposed for the selected territory, which due to the poor soil permeability at the selected locality will be located on Kuzmány Street in Košice.

These methods for trapping and accumulating rainwater reduce the burden on sewerage networks and thus also relieve the public sewerage network from rainwater. Precipitation water is an essential part of the natural water cycle, leading to water falling on the earth's surface in the form of rain. After impact on the earth's surface, it is taken, together with sinkwater, into sewerage systems, which are today at full capacity. In order to prevent this, it is advantageous to instead take rainwater to localities with permeable soils for absorption. With suitably selected systems for trapping rainwater, the negative overburdening of sewerage systems can be avoided.

\section{ACKNOWLEDGEMENT}

The contribution is written thanks to support of project VEGA 1/0609/14.

\section{REFERENCES}

[1] European Union, EU Policy Document on Natural Water Retention Measures. By the drafting team of the WFD CIS Working Group Programme of Measures (WG PoM), Luxembourg: Office for Official Publications of the European Communities, 2014.

[2] NWRM project, Concept Note: Natural Water Retention Measures (NWRM) and the WFD and Other Daughter Directives, available at http://www.nwrm.eu, January 2014 (accessed 14 November 2017). 
[3] European Union, Directive 2000/60/EC of the European Parliament and of the Council of 23 October 2000 establishing a framework for Community action in the field of water policy. Official Journal of the European Communities L 327/1.

[4] European Union, Directive 2007/60/EC of the European Parliament and of the Council of 23 October 2007 on the assessment and management of flood risks. Official Journal of the European Communities L 327/1.

[5] Markovič, G., Zeleňáková, M., Káposztásová, D. \& Hudáková, G., Rainwater infiltration in the urban areas. Environmental Impact 2, ed. G. Passerini \& C.A. Brebbia, WITT Press: Southampton, Vol. 181, pp. 313-320, 2014.

[6] Standard DWA-A 138E, Planning, Construction and Operation of Facilities for the Percolation of Precipitation Water, 2005.

[7] Macurová, M., Rainwater Management in Urban Areas (in Slovak). Thesis. Technical University Kosice, Bratislava, 2012.

[8] Zeleňáková, M. \& Hudáková, G., The concept of rainwater management in area of Košice region. Procedia Engineering: 16th Conference on Water Distribution System Analysis, WDSA2014 - Urban Water Hydroinformatics and Strategic Planning, Bari, Italy, Vol. 89, pp. 1529-1536, 2014. DOI: 10.1111/j.1747-6593.2008.00159.x.

[9] Slys, D., Potential of rainwater utilization in residential housing in Poland. Water and Environment Journal, 4, pp. 318-325, 2009.

[10] Slys, D., Stec, A. \& Zelenakova, M., A LCC analysis of rainwater management variants. Ecological Chemistry and Engineering S-Chemia i Inzynieria Ekologiczna S, 19(3), pp. 359-372, 2012. DOI: https://doi.org/10.2478/v10216-011-0026-7. 